\title{
Occurrence and quantification of Shiga toxin-producing Escherichia coli from food matrices
}

\author{
C. Sethulekshmi, C. Latha and C. J. Anu
}

\author{
Department of Veterinary Public Health, College of Veterinary and Animal Sciences, Mannuthy, Thrissur, Kerala, India. \\ Corresponding author: C. Sethulekshmi, e-mail: sethulekshmi@kvasu.ac.in \\ Co-authors: CL: latha@kvasu.ac.in, CJA: anucjose87@gmail.com \\ Received: 26-08-2017, Accepted: 05-12-2017, Published online: 03-02-2018
}

doi: 10.14202/vetworld.2018.104-111 How to cite this article: Sethulekshmi C, Latha C, Anu CJ (2018) Occurrence and quantification of Shiga toxin-producing Escherichia coli from food matrices, Veterinary World, 11(2): 104-111.

\begin{abstract}
Aim: The objective of the study was to detect Shiga toxin-producing Escherichia coli (STEC) and develop a quantitative polymerase chain reaction (qPCR) assay to quantify the bacterial DNA present in different food matrices.

Materials and Methods: A total of 758 samples were collected during a period from January 2015 to December 2016 from Kozhikode, Thrissur, and Alappuzha districts of Kerala. The samples consisted of raw milk (135), pasteurized milk (100), beef (132), buffalo meat (130), chevon (104), beef kheema (115), and beef sausage (42). All the samples collected were subjected to isolation and identification of STEC by conventional culture technique. Confirmation of virulence genes was carried out using PCR. For the quantification of STEC in different food matrices, a qPCR was standardized against stx 1 gene of STEC by the construction of standard curve using SYBR green chemistry.

Results: The overall occurrence of STEC in raw milk $(n=135)$, beef $(n=132)$, buffalo meat $(n=130)$, chevon $(n=104)$, and beef kheema $(\mathrm{n}=115)$ samples collected from Kozhikode, Thrissur, and Alappuzha districts of Kerala was 19.26\%, 41.6\%, $16.92 \%, 28.85 \%$, and $41.74 \%$, respectively. PCR revealed the presence of stx 1 and stx 2 genes in 88.46 and 83.64 and 30.77 and $40.00 \%$ of STEC isolates from raw milk and beef samples, respectively, while $100 \%$ of the STEC isolates from buffalo beef and beef kheema samples carried stx 1 gene. Real-time qPCR assay was used to quantify the bacterial cells present in different food matrices. The standard curve was developed, and the slopes, intercept, and $\mathrm{R}^{2}$ of linear regression curves were $-3.10,34.24$, and 0.99 , respectively.

Conclusion: The considerably high occurrence of STEC in the study confirms the importance of foods of animal origin as a vehicle of infection to humans. In the present study, on comparing the overall occurrence of STEC, the highest percentage of occurrence was reported in beef kheema samples. The study shows the need for rigid food safety measures to combat the potential pathogenic effects of harmful bacteria throughout the production chain from production to consumption.
\end{abstract}

Keywords: food matrices, occurrence, polymerase chain reaction, real-time quantitative polymerase chain reaction, Shiga toxigenic Escherichia coli.

\section{Introduction}

In recent years, Escherichia coli has become an organism of public health significance due to its association with life-threatening diseases in human beings. Among E. coli, Shiga toxigenic E. coli (STEC), especially the serotype O157:H7, is an emerging foodborne pathogen capable of causing potentially fatal illnesses such as hemorrhagic colitis, hemolytic uremic syndrome, and thrombocytopenic purpura in man $[1,2]$. The infection occurs in humans through the acquisition of the bacteria through consumption of contaminated food. Raw or undercooked foods from animal origin have been recognized as the most important vehicle for transmission of STEC [3-5]. Nevertheless, lack of knowledge on good hygienic practices and the prevailing unsanitary conditions in

Copyright: Sethulekshmi, et al, Open Access. This article is distributed under the terms of the Creative Commons Attribution 4.0 International License (http://creativecommons.org/licenses/ by/4.0/), which permits unrestricted use, distribution, and reproduction in any medium, provided you give appropriate credit to the original author(s) and the source, provide a link to the Creative Commons license, and indicate if changes were made. The Creative Commons Public Domain Dedication waiver (http:// creativecommons.org/publicdomain/zero/1.0/) applies to the data made available in this article, unless otherwise stated. food processing environment can cause cross-contamination of food [6].

Conventional methods used for isolation and identification of $E$. coli are ineffective for the isolation of STEC, for which specific methods are required [7]. Thus detection of STEC demands one or more selective enrichment steps followed by plating onto a selective agar [8]. Hence, for the effective isolation of STEC, the biochemical characteristics such as $\beta$-glucuronidase activity and the inability to rapidly ferment sorbitol have been exploited, and various selective and differential media have been developed [9]. As these methods are time-consuming, analytical methods based on bacterial nucleic acids are being widely used [10].

The STEC strains isolated from cattle, food, and other animal sources have various virulence profiles, and to assess the potential virulence of STEC isolates from these sources, it is important to examine them for the presence of virulence genes. The virulence of STEC strains is mainly associated with their ability to damage intestinal epithelial cells and produce Shiga toxins st 1 and or stx 2 . The polymerase chain reaction (PCR) is widely used for the detection of virulence 
factors and is known to be a sensitive and specific method. Development of quantification methods for bacterial cells in food matrices aids in the screening of food samples for the presence of potential pathogens and aids in detecting the level of contamination. The accurate quantification of stx 1 gene carrying STEC can be accomplished by real-time quantitative qPCR method $[7,11]$. The study aims to detect STEC and to develop a qPCR assay to quantify the bacterial DNA present in different food matrices.

\section{Materials and Methods}

Ethical approval

Ethical approval was not necessary for this study. However, samples were collected as per standard collection procedure described by Taylor et al. [12].

\section{Bacterial strains}

Reference culture of E. coli (MTCC 3221) was procured from the Institute Of Microbial Technology, Chandigarh, India. The STEC culture maintained in the repository of the Department of Veterinary Public Health was used for the study. The cultures were stored in nutrient broth (Difco Laboratories, Detroit, MI, USA) containing $10 \%$ sterile glycerol at $70^{\circ} \mathrm{C}$. Cultures were grown overnight $(18 \mathrm{~h})$ in Luria broth (Difco) at $37^{\circ} \mathrm{C}$ as proposed by Yang et al. [13].

\section{Collection of samples}

A total of 758 samples were collected during a period from January 2015 to December 2016 from Kozhikode, Thrissur, and Alappuzha districts of Kerala. The samples consisted of raw milk (135), pasteurized milk (100), beef (132), buffalo meat (130), chevon (104), beef kheema (115), and beef sausage (42). The aseptically collected samples were brought to the laboratory under the refrigerated condition and processed for the analysis.

\section{Isolation of STEC by conventional method}

All the samples collected were subjected to isolation and identification of STEC by conventional culture technique. The samples were transferred to TSB and homogenized. Isolation and identification of STEC from collected samples were carried out by pre-enrichment and selective enrichment followed by selective plating as described by Meng et al. [14]. The isolates were further confirmed by plating onto 4-methylumbelliferyl-beta-D-glucuronide (MUG EC) agar [15]. The colonies showing characteristics neutral gray to colorless colonies with smoky centers on CT-SMAC agar were then subjected to primary and secondary biochemical identification test. Then, the identification of virulence genes was carried out using PCR [16].

\section{Molecular characterization of STEC}

\section{Extraction of DNA from bacterial culture}

The DNA was extracted from individual bacterial cells using the QIAamp DNA Mini Kit (Qiagen), according to the manufacturer's instructions. The bacterial cells from a $250 \mu 1$ aliquot of culture were obtained by centrifugation $\left(14000 \mathrm{~g}, 2 \mathrm{~min}, 18 \pm 20^{\circ} \mathrm{C}\right)$ and resuspended in $45 \mu \mathrm{l} 10 \mathrm{mM}$ phosphate buffer, $\mathrm{pH} 6 \pm 7$, before freezing at $-20^{\circ} \mathrm{C}$. The frozen cells were then heated in a boiling water bath for $10 \mathrm{~min}$.

The calculation of target DNA copies was done with the following equation: Number of copies $($ molecules $)=X$ ng $\times 6.0221 \times 10^{23}$ molecules per mole/ $\left.(\mathrm{N} \times 660 \mathrm{~g} / \mathrm{mole}) \times 10^{-9} \mathrm{ng} / \mathrm{g}\right)$, where $\mathrm{X}$ is the mass in nanogram, and $\mathrm{N}$ is the length of the genomic DNA [17].

\section{Primers used for the identification of STEC stx 1, stx 2, eae A, and hly A genes}

Four oligonucleotide primers, targeting the Shiga toxin gene 1 (stx1), Shiga toxin gene 2 (stx2), Enteroeffacement gene A (eaeA), and Enterohemolysin A ( hlyA) was used in the study for the detection of STEC (Table-1) [16,18,19].

\section{Setting up of PCR}

The PCR reaction mixture was a total of $25 \mu \mathrm{L}$ containing $2.5 \mu \mathrm{L}$ DNA extract, $2.5 \mu \mathrm{L}$ of $10 \times$ buffer $\left(\right.$ Sigma $\left.^{\circledR}\right), 2.0 \mu \mathrm{L}$ of $10 \mathrm{mMdNTPs}$ mix $\left(\right.$ Fermentas $\left.^{\circledR}\right)$, $1.0 \mu \mathrm{L}$ of $20 \mu \mathrm{M}$ primers, $2.5 \mu \mathrm{L}$ of $25 \mathrm{mM} \mathrm{MgCl}_{2}$, and $1 \mathrm{U}$ of Taq Polymerase (Fermentas ${ }^{\circledR}$ ). PCR amplification was performed in an automated thermal cycler (Eppendorf Master Cycler, Germany) with initial denaturation at $95^{\circ} \mathrm{C}$ for $7 \mathrm{~min}$. This was followed by 40 cycles of denaturation at $95^{\circ} \mathrm{C}$ for $1 \mathrm{~min}$; annealing at $56^{\circ} \mathrm{C}$ for $s t x 1$ for $40 \mathrm{~s}$ and $61.6^{\circ} \mathrm{C}$ for stx 2 for $1 \mathrm{~min}$; and $61^{\circ} \mathrm{C}$ for $1 \mathrm{~min}$ for eaeA and hlyA followed by extension at $72^{\circ} \mathrm{C}$ for $10 \mathrm{~min} .10 \mu \mathrm{L}$ of the PCR product was electrophoresed in an agarose gel $(1.5 \%)$ containing $5 \mu \mathrm{L}$ of $10 \mathrm{mg} / \mathrm{ml}$ ethidium bromide at 80 $\mathrm{V}$ for 60 min. 50 bp DNA marker (Fermentas ${ }^{\circledR}$ ) was used as molecular size marker. DNA amplifications were examined and results documented using Gel Documentation System $\left(\right.$ Syngene $\left.{ }^{\circledR}\right)$.

\section{Real-time PCR assay for quantification of STEC}

The standardization of qPCR for gene stx 1 of STEC was achieved by construction of standard curve using SYBR green chemistry. Standard curves were generated for quantification purposes using genomic DNA (carrying stx 1 gene). Serial dilutions ranging from $10^{1}$ to $10^{7}$ were prepared using $1 \mu \mathrm{L}$ of the target DNA concentration (copies of DNA) assuming that one copy of DNA is equal to one colony-forming unit (CFU). The same primer pairs used in the traditional PCR were used to construct a standard curve as well as to ascertain the possible detection limit.

The maxima SYBR Green qPCR master mix (2X) with ROX was procured from Thermo Scientific India. The preparation of master mix included all reaction components except template DNA. The reactions were performed (Applied Biosystems, Sweden) in a final volume of $12.5 \mu \mathrm{L}$ reaction mixture using Maxima SYBR Green/ROX qPCR $6.25 \mu \mathrm{L}$ and forward and reverse primer $(10 \mathrm{pM} / \mu \mathrm{l}) 0.5 \mu \mathrm{L}$ each. The reaction conditions for amplification of DNA were 


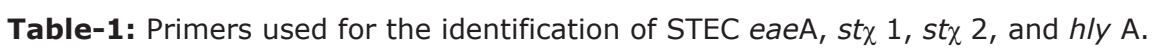

\begin{tabular}{|c|c|c|c|c|c|}
\hline Genes & Primer & Length & Primer sequence & Size of amplicon (bp) & References \\
\hline \multirow[t]{2}{*}{ eae $A$} & $\mathrm{~F}$ & 20 & 5'-CTGAACGGCG ATTACGCGAA-3' & 917 & [18] \\
\hline & $\mathrm{R}$ & 18 & 5'-CCAGACGAT ACGATCCAG- $3^{\prime}$ & & \\
\hline \multirow[t]{2}{*}{$S t_{\chi} 1$} & $\mathrm{~F}$ & 23 & 5'ATAAATCGCCAT TCGTTGACTAC - 3' & 180 & [16] \\
\hline & $\mathrm{R}$ & 21 & $\begin{array}{l}5^{\prime}-\text { AGAACGCCCA } \\
\text { CTGAGATCATC- } 3^{\prime}\end{array}$ & & \\
\hline \multirow[t]{2}{*}{$S t \chi 2$} & $\mathrm{~F}$ & 21 & 5'-GGCACTGTCT GAAACTGCTCC-3' & 255 & [18] \\
\hline & $\mathrm{R}$ & 22 & 5'-TCGCCAGTTAT CTGACATTCTG- 3' & & \\
\hline \multirow[t]{2}{*}{ hlyA } & $\mathrm{F}$ & 20 & $\begin{array}{l}\text { 5'-TGGTGCAGCA } \\
\text { GAAAAAGTTG3' }\end{array}$ & 244 & [19] \\
\hline & $\mathrm{R}$ & 20 & $\begin{array}{l}\text { 5'-ATCCTCTCC } \\
\text { TTCCCGTTGTT3' }\end{array}$ & & \\
\hline
\end{tabular}

$95^{\circ} \mathrm{C}$ for $10 \mathrm{~min}, 40$ cycles of $95^{\circ} \mathrm{C}$ for $15 \mathrm{~s}$, and $56^{\circ} \mathrm{C}$ for $40 \mathrm{~s}$. The reaction included a positive control and a non-template control used as a negative control to check possible reagent contamination.

Data analysis made use of Sequence Detection Software version 1.6.3 supplied by Applied Biosystems. The standard curve was calculated by plotting the log of starting a quantity of DNA copy numbers against cycle threshold $(\mathrm{Ct})$ values generated. A melt curve was generated to verify the product by its specific melting temperature.

\section{Statistical analysis}

The data obtained were subjected to statistical analysis using the SPSS version 21.0. The Fisher's exact test was used to assess the significance of the occurrence of STEC within the same sample between different sources within the same district as well as between districts.

Cochran's Q-test was used to compare the occurrence of virulence genes in STEC organisms. This test was used to determine whether there was any statistically significant difference between $s t x 1, s t x 2, h l y \mathrm{~A}$, and eae A genes in STEC isolates.

\section{Results}

\section{Occurrence of STEC by conventional method}

The highest occurrence $(37.50 \%)$ of STEC was detected in raw milk samples collected from Alappuzha district. However, STEC was isolated from $12 \%$ and $11.11 \%$ of samples belonging to Thrissur and Kozhikode districts. An overall occurrence of the organism was observed in $19.26 \%$ of raw milk samples from the three districts. Statistical analysis by Fisher's exact test showed a significant difference $(p \leq 0.05)$ in the occurrence of STEC in raw milk samples between districts. The samples collected from Kozhikode and Thrissur differed significantly from those collected from Alappuzha district (Table-2). STEC was not detected in any of the pasteurized milk samples collected from the three districts.

Occurrence of STEC was highest in beef samples collected from Alappuzha (53.33\%). Samples from Kozhikode and Thrissur were contaminated with the organism at the rate of $31.82 \%$ and $43.10 \%$. The STEC was present in 55 samples of a total 132 beef samples examined. Occurrence of STEC was high in buffalo meat samples collected from Thrissur. Thirteen samples revealed the presence of the organism. However, seven and two STEC isolates were recovered from samples from Kozhikode and Alappuzha, respectively. An overall occurrence of STEC was detected in $16.92 \%$ of samples. The statistical analysis by Fisher's exact test revealed that, in buffalo meat, the occurrence of STEC in Thrissur significantly differed $(\mathrm{p} \leq 0.05)$ from that of Alappuzha district. The STEC was isolated from more than $30 \%$ of chevon samples from Thrissur and Alappuzha. The $16.67 \%$ of chevon samples from Kozhikode showed the presence of the organism. An overall occurrence of $28.85 \%$ of STEC was reported in chevon samples from the three districts. The occurrence of STEC organism in beef kheema was in the order of 16, 17, and 15 samples, respectively, from Kozhikode, Thrissur, and Alappuzha districts. A total of $41.74 \%$ samples showed the presence of the organism. The beef sausage samples examined did not reveal the presence of STEC in any of the samples examined.

\section{Occurrence of STEC virulence genes in different samples}

The STEC detected in 26 raw milk samples by conventional culture method was subjected to PCR for the confirmation. All the 26 positive isolates were identified to carry either of stx $1, s t x 2$, or hlyA genes using PCR. The gene stx 1 was detected in 23 isolates, while eight of the isolates carried stx 2 gene, of which five isolates carried both stx 1 and stx 2 genes. The hlyA genes were detected in combination with two and one isolates carrying stx 1 and stx 2 genes, respectively. However, eaeA gene was not be detected in any of the positive isolates. The statistical analysis was done using Cochran's Q-test which revealed that the occurrence of gene stx 1 was significantly different $(p \leq 0.05)$ from that of all other genes in positive isolates from raw milk samples. All of the positive isolates derived from beef, buffalo meat, chevon, and beef kheema were identified to carry either of $s t x 1$, stx 2, eaeA, and hly A genes using PCR (Figure-1). The gene stx 1 was identified in cent $\%$ of positive isolates from buffalo meat and beef kheema samples (Table-3). While STEC isolated from beef and chevon 
Table-2: Occurrence of STEC in different food matrices.

\begin{tabular}{|c|c|c|c|c|c|c|}
\hline \multirow[t]{3}{*}{ Meat samples } & \multicolumn{6}{|c|}{ Districts } \\
\hline & \multicolumn{2}{|c|}{ Kozhikode } & \multicolumn{2}{|c|}{ Thrissur } & \multicolumn{2}{|r|}{ Alappuzha } \\
\hline & $\begin{array}{l}\text { Total } \\
\text { samples }\end{array}$ & $\begin{array}{l}\text { STEC-positive } \\
\text { samples n (\%) }\end{array}$ & $\begin{array}{l}\text { Total } \\
\text { samples }\end{array}$ & $\begin{array}{l}\text { STEC-positive } \\
\text { samples n }(\%)\end{array}$ & $\begin{array}{l}\text { Total } \\
\text { samples }\end{array}$ & $\begin{array}{c}\text { STEC-positive samples } \\
\text { n (\%) }\end{array}$ \\
\hline Raw milk & 45 & $5\left(11.11^{\mathrm{a}}\right)$ & 50 & $6\left(12.00^{\mathrm{a}}\right)$ & 40 & $15\left(37.50^{\mathrm{b}}\right)$ \\
\hline Beef & 44 & $14\left(31.82^{\mathrm{a}}\right)$ & 58 & $25\left(43.10^{a}\right)$ & 30 & $16\left(53.33^{a}\right)$ \\
\hline Buffalo meat & 40 & $7\left(17.50^{a, b}\right)$ & 46 & $13\left(28.26^{b}\right)$ & 44 & $2(4.55 a)$ \\
\hline Chevon & 30 & $5\left(16.67^{a}\right)$ & 42 & $14\left(33.33^{a}\right)$ & 32 & $11\left(34.38^{\mathrm{a}}\right)$ \\
\hline Beef Kheema & 40 & $16\left(40.00^{a}\right)$ & 40 & $17\left(42.50^{a}\right)$ & 35 & $15\left(42.86^{a}\right)$ \\
\hline Beef Sausage & 12 & $0\left(0.00^{a}\right)$ & 14 & $0(0.00 a)$ & 16 & $0\left(0.00^{a}\right)$ \\
\hline Total & 166 & $42(25.30)$ & 200 & $69(34.50)$ & 157 & $44(28.03)$ \\
\hline
\end{tabular}

Figures bearing the same superscript in the same row do not differ significantly $(p \leq 0.05)$. STEC=Shiga toxin-producing Escherichia coli

Table-3: Occurrence of STEC virulence genes (\%) in different samples.

\begin{tabular}{lccccc}
\hline Virulence genes & Raw milk & Beef & Buffalo meat & Chevon & Meat products \\
\hline st $\chi 1$ & $88.46^{\mathrm{a}}$ & $83.64^{\mathrm{a}}$ & $100.00^{\mathrm{a}}$ & $83.33^{\mathrm{a}}$ & $100^{\mathrm{a}}$ \\
st 2 & $30.77^{\mathrm{b}}$ & $40.00^{\mathrm{b}}$ & $27.27^{\mathrm{b}}$ & $26.67^{\mathrm{b}}$ & $41.67^{\mathrm{b}}$ \\
eae A & $0^{\mathrm{b}}$ & $7.27^{\mathrm{c}}$ & $4.54^{\mathrm{b}}$ & $6.67^{\mathrm{b}}$ & $12.5^{\mathrm{b}}$ \\
hlyA & $11.5^{\mathrm{b}}$ & $23.64^{\mathrm{c}, \mathrm{b}}$ & $22.73^{\mathrm{b}}$ & $20.00^{\mathrm{b}}$ & $14.58^{\mathrm{b}}$ \\
Total isolate & 26 & 55 & 22 & 30 & 48 \\
\hline
\end{tabular}

Figures bearing the same superscript within the same column do not differ significantly $(\mathrm{p} \leq 0.05)$. STEC=Shiga toxin-producing Escherichia coli

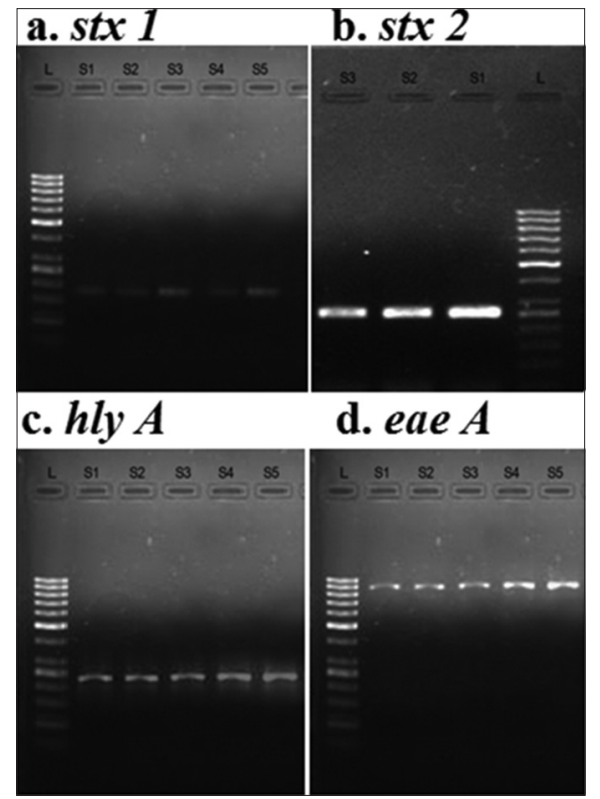

Figure-1: PCR results for virulence genes of EHEC.

samples harbored stx 1 gene in $83.64 \%$ and $83.33 \%$ of the isolates. The stx 2 gene was identified in $40 \%$ and $26.67 \%$ STEC isolates in beef and chevon samples, respectively. The STEC isolates from meat and meat product samples also harbored genes hly A and eae A in combination with either of stx 1 or stx 2 or both genes. A high \% (12.50) of eaeA gene carrying isolates was found in beef kheema, in combination with stx 1 gene. The statistical analysis using Cochran' Q-test which revealed that the occurrence of gene stx 1 was significantly different $(p \leq 0.05)$ from that of all other genes in all the samples. The isolates from beef samples showed a significant difference in the occurrence of stx 1 genes to that of stx $2, h l y \mathrm{~A}$, and eaeA genes, but no significant difference was noticed between stx 2 and $h l y \mathrm{~A}$ genes. However, eaeA gene differed significantly from that of stx 1 and stx 2 genes but not with that of hly A genes.

\section{Quantitation of STEC by real-time PCR}

One microliter of DNA containing $4.09 \times 10^{8}$ copies of stx 1 gene was subjected to serial dilution ranging from $10^{1}$ to $10^{7}$. Ct values increased at each dilution with the corresponding decrease in target DNA concentration. This clearly demonstrated the validity of the assay, showing that quantification of target DNA is possible. Amplification plot generated corresponding to the standard curve showed a linear correlation between $\log _{10}$ copy numbers and $\mathrm{Ct}$ with slope values and $\mathrm{R}^{2}$ values (Figures-2-4). The slopes, intercept, and $\mathrm{R}^{2}$ values of linear regression curves were $-3.10,34.24$, and 0.99 , respectively. The melting temperature was determined at $79.1^{\circ} \mathrm{C}$.

The representative samples from different sources which were positive for STEC by PCR were quantified using real-time PCR (Table-4). The concentration of DNA copies in unknown samples was estimated from the standard curve assuming that one copy of DNA is one CFU. The Ct values corresponding to the log of copy numbers gives the unknown sample concentration.

\section{Discussion}

Globally, STEC is regarded as the major cause of foodborne disease outbreaks. Consumption of contaminated foods of animal origin plays an important 


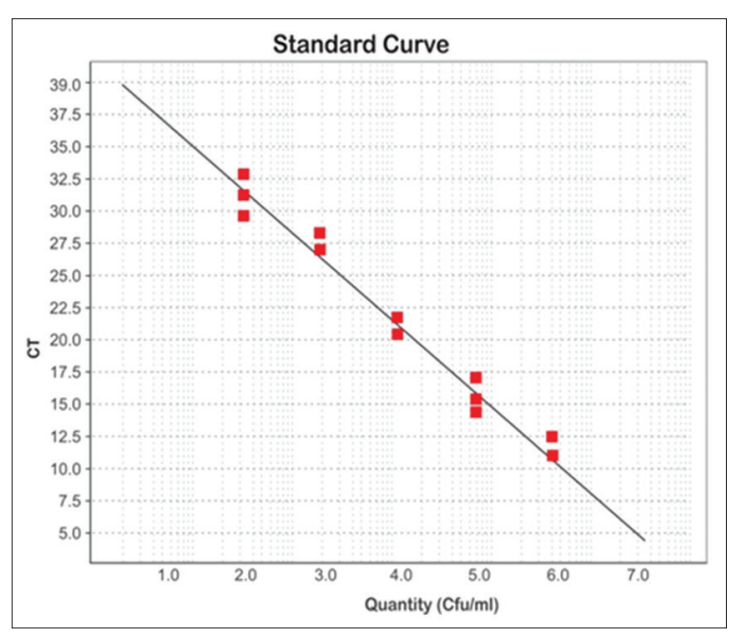

Figure-2: Standard curve of Enterohaemorrhagic E. coli.

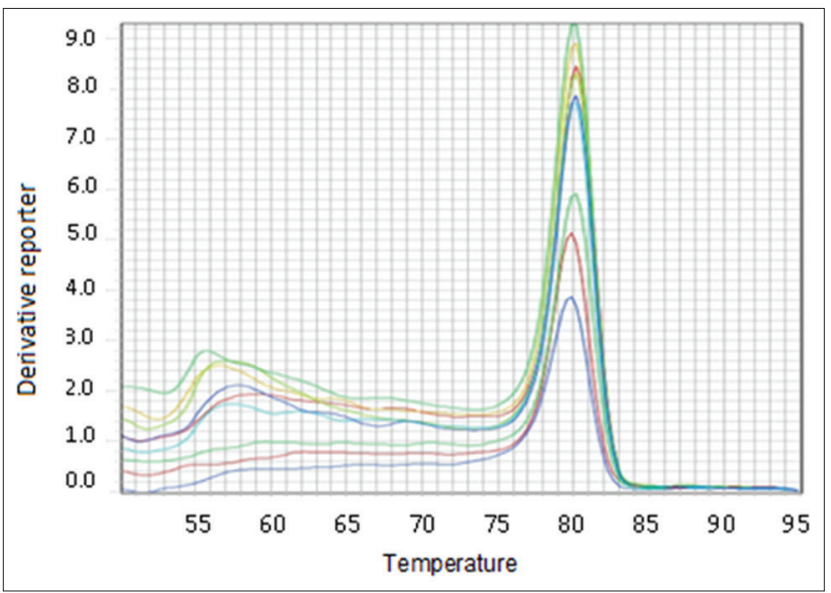

Figure-3: Melt curve for EHEC.

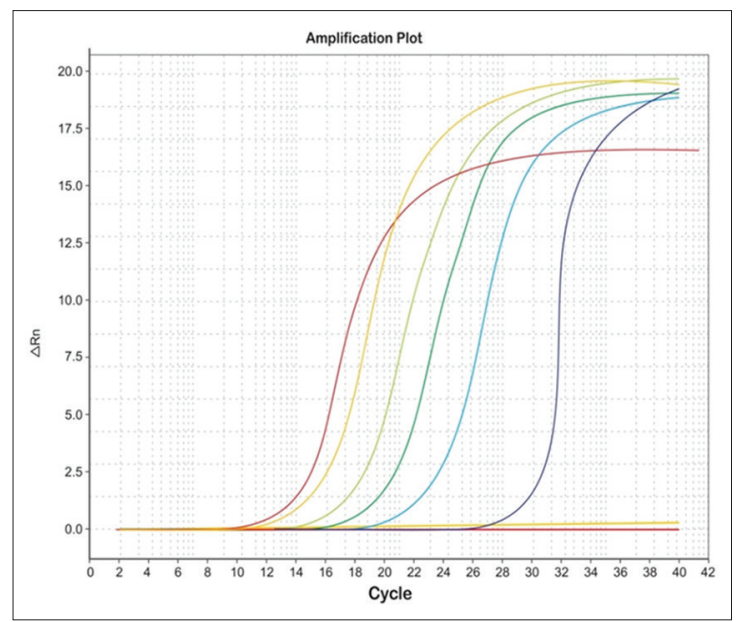

Figure-4: Amplification plot of EHEC.

role in STEC transmission as ruminants are known reservoirs for STEC.

In the present study, maximum STEC contamination in raw milk samples was observed in the samples collected from Alappuzha district, where STEC was recovered from $37.50 \%$ of samples. Statistical analysis showed a significant difference in the occurrence of STEC in Alappuzha district from rest of the districts. Various studies showed the prevalence of EHEC
Table-4: Result of quantitative detection of STEC by real-time PCR.

\begin{tabular}{lc}
\hline Sources & Mean count \pm SD $($ CFU $/ \mathbf{m I})$ \\
\hline Raw milk & $1.0 \times 10^{1} \pm 0.18$ \\
Beef & $3.2 \times 10^{4} \pm 0.12$ \\
Buffalo meat & $2.7 \times 10^{4} \pm 0.26$ \\
Chevon & $3.0 \times 10^{2} \pm 0.13$ \\
Beef kheema & $3.4 \times 10^{4} \pm 0.16$ \\
\hline
\end{tabular}

STEC $=$ Shiga toxin-producing Escherichia coli, $\mathrm{PCR}=$ Polymerase chain reaction, $\mathrm{CFU}=$ Colony-forming unit, $\mathrm{SD}=$ Standard deviation

in raw milk samples at different levels. A considerable number of isolation of EHEC in milk samples were made by many investigators. The milk samples which were positive for the organisms in the earlier studies were from individual as well as from bulk milk samples. This means that the milk is contaminated at the production level itself. In the present study, individual milk samples were collected from the milk societies before they were pooled directly from the farmer. Hence, the results indicate that the hygienic condition at the production level is far below. The contaminated udder, environment, or the milkers might have contributed the organisms to the milk. Similar results as of the present study were obtained by Mohammadi et al. [20] who had reported an overall prevalence of $17.47 \%$ for STEC in 206 raw milk samples collected from Kermanshah, Iran. Fecal contamination due to poor hygiene is a potential risk factor for the presence of pathogenic organisms in milk. The considerably high occurrence of STEC in the study confirms the importance of raw milk as a vehicle of infection to human.

The organism was not be isolated from any of the pasteurized milk samples examined. The previous studies carried out by Junior et al. [21] and Hoffmann et al. [22] also reported that the pasteurized milk was free from STEC. The above findings revealed that pasteurization aids in the effective elimination of pathogen from raw milk. Hence, consumption of pasteurized milk is a safe practice to prevent milk-borne STEC outbreaks.

On comparing the overall occurrence of STEC, highest $\%$ of occurrence was reported in beef kheema samples. The STEC in these samples had been detected at a rate of $41.74 \%$ of samples. Temelli et al. [23] reported a similar occurrence rate to that of the present study in ground beef samples examined. Fantelli and Stephan [24] and Maktabi et al. [25] reported a lower occurrence rate of $2.3 \%$ and $1.5 \%$ than the present study from minced beef samples. Next to beef kheema, beef samples represented the highest \% in the occurrence of STEC. The beef samples were contaminated with STEC at a rate of $41.67 \%$, followed by chevon $(28.84 \%)$ and buffalo meat $(16.92 \%)$ samples. Arthur et al. [26] recovered STEC from 43.4\% of pre-eviscerated beef carcasses. The comparatively higher occurrence rate of EHEC obtained in the study 
could be attributed to the asymptomatic carriage of EHEC in the farm animals and the fecal contamination of the meat during slaughter. Moreover, the animals are slaughtered in abattoirs and sometimes in the backyards without observing hygienic practices. Butchers and meat sellers pay little attention to their personal hygiene. The cutting table and the knives used were not sanitized properly. Moreover, meat was sold in open markets. Rahimi et al. [27] reported the presence of STEC in $8.2 \%, 5.3 \%$, and $1.3 \%$ of beef, water buffalo, and chevon samples, respectively, which is lower than the present study. A higher occurrence than the present study was reported by Sinha et al. [28] who had isolated STEC from $37.33 \%$ of buffalo meat samples belonging to Gujarat, India. The presence of STEC has been reported previously in goat meats [29-31]. Momtaz et al. [32] reported an isolation of STEC from $18.66 \%$ of ruminant meat samples. The lack of hygienic slaughterhouses along with unhygienic post slaughter facilities might have contributed to the relatively high occurrence of STEC in buffalo beef samples.

The detection of virulence genes in the STEC isolates is a clear confirmation of result obtained in the conventional culture method. Among the STEC isolates from various food matrices, stx 1 gene was more predominantly found than the stx 2 gene, followed by hly A and eaeA genes. Similar findings were reported in studies carried out by Rashid et al. [33] and Ranjbar et al. [34] where stx 1 was more frequently detected than stx 2 and ehly genes. The presence of virulence genes in the isolates indicates that the STEC organism present in the meat and meat products were of highly pathogenic in nature and can cause a serious public health hazard.

In the present study, real-time PCR was standardized by creating standard curves for stx 1 gene. The target gene used in the study was previously used by Ibekwe et al. [35] for quantification of E. coli $\mathrm{O} 157: \mathrm{H} 7$ in environmental samples. The real-time PCR has been used to quantify STEC organisms from food and environmental samples by Bellin et al. [36]. For detection of STEC from food, Hara-Kudo et al. [37] found that the real-time PCR was more sensitive than the conventional culture technique. The $\mathrm{Ct}$ is the number of cycles required for the fluorescent signal to cross the threshold. The $\mathrm{Ct}$ values are inversely proportional to the amount of target nucleic acid in the sample [38]. In the present study also, $\mathrm{Ct}$ values increased at each dilution, demonstrating the validity of the assay as the target DNA concentration decreased with each cycle and showed that the quantification of target DNA is possible.

Quantitative real-time PCR analysis of the raw milk, beef, buffalo beef, chevon, and beef kheema samples for the stx genes with the standard curves revealed linearity between the $\mathrm{Ct}$ values and the starting quantity of DNA copy numbers. These standard curves were used for estimating the numbers of
STEC in the samples. The ability to quantify STEC in different samples will aid in developing models of pathogen transport in the environment and subsequently assist in the development of risk assessment strategy. Bono et al. [39] used real-time PCR to detect $\mathrm{STEC}$. The average $\mathrm{Ct}$ of the $E$. coli $\mathrm{O} 157$ isolates was 27 cycles. They reported that 87 of the 102 non-E. coli O157 isolates from beef samples did not amplify after 45 cycles and thus had no $\mathrm{Ct}$ values. According to Ibekwe et al. [35], the Ct values showed a linear relationship with the number of E. coli O157:H7 organisms added, indicating a direct correlation between the $\mathrm{Ct}$ and the number of E. coli $\mathrm{O} 157: \mathrm{H} 7 \mathrm{CFU}$ per $\mathrm{g}$ of feces. The above results indicate that the real-time qPCR assay is useful in screening the foods of animal origin carrying Shiga toxin genes.

\section{Conclusion}

STEC is an emerging foodborne pathogen of public health importance that hit the food industry over the past two decades. This study was performed with the objective of assessing the occurrence of STEC in different samples from different sources, screening the positive isolates for the presence of virulence genes, and quantifying the organism in the positive samples. The results of the study revealed the ubiquitous nature of STEC and its widespread presence in the foods of animal origin. The increased trend toward globalization has adversely affected the current food scenario by the advertent importation of contaminated foods. The findings of the study suggest the need to develop strategies to reduce STEC in foods which will depend much on hygienic and sanitary production and processing practices. Thus, the colonization, transmission, and cross-contamination of STEC in foods and the environment can be minimized. An effective control measure for this pathogen has to target the farm, processing plants and the environments. At all these stages, strict adherence to standard operating measures must be practiced.

\section{Author's Contributions}

CS collected the samples, carried out the laboratory work. CL supervised the research work, reviewed the manuscript, and provided guidance for research work. ACJ contributed to the molecular work of the study and revised the manuscript. All authors read and approved the findings of the manuscript.

\section{Acknowledgments}

The authors would like to thank the Kerala Veterinary and Animal Sciences University for providing the facilities to carry out the research work. The research received no specific grant from any funding agencies.

\section{Competing Interests}

The authors declare that they have no competing interests. 


\section{References}

1. Yamasaki, E., Watahiki, M., Isobe, J., Sata, T., Nair, G.B. and Kurazono, H. (2015) Quantitative detection of shiga toxins directly from stool specimens of patients associated with an outbreak of enterohemorrhagic Escherichia coli in Japan-quantitative shiga toxin detection from stool during EHEC outbreak. Toxins, 7(10): 4381-4389.

2. Hiraka, T., Kanoto, M., Sugai, Y., Honma, T., Makino, N., Ueno, Y. and Hosoya, T. (2015) Computed tomographic findings of enterohemorrhagic Escherichia coli $\mathrm{O} 157$ infection: An analysis of a 7-case regional outbreak. J. Comput. Assist. Tomo.,39(3): 406-408.

3. Kiranmayi, C.B. and Krishnaiah, N. (2010) Detection of Escherichia coli O157: H7 prevalence in foods of animal origin by cultural methods and PCR technique.Vet. World, 3(1): 13-16.

4. Dhama, K., Rajagunalan, S., Chakraborty, S., Verma, A.K., Kumar, A., Tiwari, R. and Kapoor, S. (2013) Food-borne pathogens of animal origin-diagnosis, prevention, control and their zoonotic significance: A review. Pak. J. Biol. Sci.,16(20): 1076-1085.

5. Suzuki, H. and Okada, Y. (2014) Enterohemorrhagic Escherichia coli (EHEC) Infection and Beef Consumption in Japan. In: Proceeding of $2^{\text {nd }}$ AFSSA Conference on Food Safety and Food Security. pp79-82.

6. Diercke, M., Kirchner, M., Claussen, K., Mayr, E., Strotmann, I., Frangenberg, J., Schiffmann, A., BettgeWeller, G., Arvand, M. and Uphoff, H. (2014) Transmission of shiga toxin-producing Escherichia coli O104: H4 at a family party possibly due to contamination by a food handler, Germany 2011. Epidemiol. Infect., 142(1): 99-106.

7. Lozinak, K.A., Jani, N., Gangiredla, J., Patel, I., Elkins, C.A., Hu, Z., Kassim, P.A., Myers, R.A. and Laksanalamai, P. (2016) Investigation of potential shiga toxin producing Escherichia coli (STEC) associated with a local foodborne outbreak using multidisciplinary approaches. Food Sci., 5(3): 163-168.

8. Conrad, C., Stanford, K., McAllister, T., Thomas, J. and Reuter, T. (2016) Shiga toxin-producing and current trends in diagnostics. Anim. Frontiers., 6(2): 37-43.

9. Verhaegen, B., De Reu, K., Heyndrickx, M. and De Zutter, L. (2015) comparison of six chromogenic agar media for the isolation of a broad variety of non-O157 shigatoxin-producing Escherichia coli (STEC) serogroups. Int. J. Environ. Res. Public. Health.,12(6): 6965-6978.

10. Zhao, X., Lin, C.W., Wang, J. and Oh, D.H. (2014) Advances in rapid detection methods for foodborne pathogens. J. Microbiol. Biotechnol.,24(3): 297-312.

11. Noll, L.W., Shridhar, P.B., Shi, X., An, B., Cernicchiaro, N., Renter, D.G., Nagaraja, T.G. and Bai, J. (2015) A fourplex real-time PCR assay, based on rfb E, stx 1, stx 2, and eae genes, for the detection and quantification of shiga toxin-producing Escherichia coli $\mathrm{O} 157$ in cattle faeces. Foodborne Pathog. Dis., 12(9): 787-794.

12. Taylor, M.T., Sofos, J.N., Bodnaruk, P. and Acuff, G.R. (2015) Sampling plans, sample collection, shipment and preparation for analysis. In: Downes FP, Ito K. $5^{\text {th }}$ ed. Compendium of Methods for the Microbiological Examination of Foods. Washington DC: American Public Health Association.

13. Yang, X., Cheng, H.W., Chen, L., Zhao, J., Chang, H.T., Wang, X.W., Liu, H.Y., Yao, H.X., Zhang, L.X. and Wang, C.Q. (2013) A duplex SYBR Green I real-time quantitative PCR assay for detecting Escherichia coli O157: H7. Genet. Mol. Res.12(4): 4836.

14. Meng, J., Zhao, S., Doyle, M.P., Mitchell, S.E. and Kresovich, S. (2001) A multiplex PCR for identifying Shiga toxin producing E. coli. Lett. Appl. Microbiol., 24: 172-176.

15. Fujisawa, T., Sata, S., Aikawa, K., Takahashi, T., Yamai, S. and Shimada, T. (2000) Modification of sorbitol mac conkey medium containing cefixime and tellurite for isolation of Escherichia coli 0157: H7 from radish sprouts. Appl.
Environ. Microbiol.,66: 3117-3118.

16. Paton, A.W. and Paton, J.C. (1998) Detection and characterization of shiga toxigenic Escherichia coli by using multiplex PCR assays for stx1, stx 2, eae A, enter haemorrhagic E. coli hly A, rfb O111, and rfbO157. J. Clin. Microbiol., 36: 598- 602.

17. Adam, P.S. (2006) Data analysis and reporting. In: Dorak MT, editors. Real time PCR. Abingdon: Taylor \& Francis Group. pp39-59.

18. Aranda, K.R., Fagundes-Neto, U. and Scaletsky, I.C.A. (2004) Evaluation of multiplex PCR for diagnosis of infection with diarrheagenic Escherichia coli and Shigella spp. J. Clin. Microbiol.,42: 5849-5853.

19. Anu, P.J. (2015) Identification of Critical Control Points in Beef Processing Line with Special Reference to Enterohaemorrhagic Escherichia coli. M.V.Sc Thesis, Kerala Veterinary and Animal Sciences University, Pookode. p86.

20. Mohammadi, P., Abiri, R., Rezaei, M. and SalmanzadehAhrabi, S. (2013) Isolation of shiga toxin-producing Escherichia coli from raw milk in Kermanshah, Iran. Iran. J. Microbiol., 5(3): 233-238.

21. Junior, L.B.R., Oliveira, P.M., Silva, F.J.M., Gomes, A.P., Martins, M.L., Santos, M.T., Moraes, C.A. and Junior, A.S. (2014) Occurrence of shiga toxin-producing Escherichia coli (STEC) in bovine faeces, feed, water, raw milk, pasteurized milk, Minas Frescal cheese and ground beef samples collected in Minas Gerais, Brazil. Int. Food Res. J., 21(6): 2481-2486.

22. Hoffmann, S.A., Pieretti, G.G., Fiorini, A., Patussi, E.V., Cardoso, R.F. and Mikcha, J.M.G. (2014) Shiga-Toxin genes and genetic diversity of Escherichia coli isolated from pasteurized cow milk in Brazil. J. Food Sci.,79(6): $1175-1180$.

23. Temelli, S., Eyigor, A. and Anar, S. (2012) Prevalence of Escherichia coli $\mathrm{O} 157$ in red meat and meat products determined by VIDAS ECPT and light cycler PCR. Turk.J. Vet. Anim. Sci., 36: 305-310.

24. Fantelli, K. and Stephan, R. (2001) Prevalence and characteristics of shigatoxin-producing Escherichia coli and Listeria monocytogenes strains isolated from minced meat in Switzerland. Int. J. Food Microbiol.,70(1): 63-69.

25. Maktabi, S., Zarei, M. and Mohammadpour, H. (2016) Isolation and molecular characterization of non-sorbitol fermenting Escherichia coli isolated from fresh ground beef Jundishapur. J. Health. Sci., 8(1): 20-24.

26. Arthur, T.M., Barkocy-Gallagher, G.A., Rivera-Betancourt, M. and Koohmaraie, M. (2002) Prevalence and characterization of non-O157 Shiga toxin-producing Escherichia coli on carcasses in commercial beef cattle processing plants. Appl. Environ. Microbiol.,68: 4847-4852.

27. Rahimi, E., Kazemeini, H.R. and Salajegheh, M. (2012) Escherichia coli O157: H7/NM prevalence in raw beef, camel, sheep, goat and water buffalo meat in Fars and Khuzestan provinces, Iran. Vet. Res. Forum., 3: 13-17.

28. Sinha, N., Kshirsagar, D.P., Brahmbhatt, M.N. and Nayak, J.B. (2015) Detection and virulence gene characterization of shiga toxigenic $E$. coli from buffalo meat samples. Indian J. Anim. Res., 49(5): 694-698.

29. Barlow, R.S., Gobius, K.S. and Desmarchelier, P. (2006) Shiga toxin producing Escherichia coli in ground beef and lamb cuts: results of a one-year study. Int. J. Food Microbiol., 111: 1-5.

30. Miko, A., Pries, K., Haby, S., Steege, K., Albrecht, N., Krause, G. and Beutin, L. (2009) Assessment of shiga toxin-producing Escherichia coli isolates from wildlife meat as potential pathogens for humans. Appl. Environ. Microbiol., 75: 6462-6470.

31. Ojo, O.E., Ajuwape, A.T.P., Otesile, E.B., Owoade, A.A., Oyekunle, M.A. and Adetosoye, A.I. (2010) Potentially zoonotic Shiga toxin-producing Escherichia coliserogroups in 
the faeces and meat of food-producing animals in Ibadan, Nigeria. Int. J. Food Microbiol., 142: 214-221.

32. Momtaz, H., Dehkordi, F.S., Rahimi, E., Ezadi, H. and Arab, R. (2013) Incidence of shiga toxin-producing Escherichia coli serogroups in ruminant's meat. Meat Sci.,95(2): 381-388.

33. Rashid, M., Kotwal, S.K., Malik, M.A. and Singh, M. (2013) Prevalence, genetic profile of virulence determinants and multidrug resistance of Escherichia coli isolates from foods of animal origin. Vet. World, 6: 139-142.

34. Ranjbar, R., Masoudimanesh, M., Dehkordi, F.S., Jonaidi-Jafari, N. and Rahimi, E. (2017) Shiga (Vero)toxin producing Escherichia coli isolated from the hospital foods; Virulence factors, o-serogroups and antimicrobial resistance properties. Antimicrob Resist Infect Ctrol.,6(1): 4-15.

35. Ibekwe, A.M., Watt, P.M., Grieve, C.M., Sharma, V.K. and Lyons, S.R. (2002) Multiplex fluorogenic real time PCR for detection and quantification of Escherichia coli O157: H7 in dairy waste water wetlands. Appl. Environ.
Microbiol.,68: 4853-4862.

36. Bellin, T., Pulz, M., Matussek, A., Hempen, H.G. and Gunzer, F. (2001) Rapid detection of enterohemorrhagic Escherichia coli by real-time PCR with fluorescent hybridization probes. J. Clin. Microbiol., 39: 370-374.

37. Hara-Kudo, Y., Konishi, N., Ohtsuka, K., Iwabuchi, K., Kikuchi, R., Isobe, J., Yamazaki, T., Suzuki, F., Nagai, Y., Yamada, H. and Tanouchi, A. (2016) An interlaboratory study on efficient detection of Shiga toxin-producing Escherichia coli $\mathrm{O} 26, \mathrm{O} 103, \mathrm{O} 111, \mathrm{O} 121, \mathrm{O} 145$, and $\mathrm{O} 157$ in food using real-time PCR assay and chromogenic agar. Int. J. Food Microbiol.,230: 81-88.

38. Fukushima, H. and Seki, R. (2004) High numbers of Shiga toxin-producing Escherichia coli found in bovine faeces collected at slaughter in Japan. FEMS Microbiol. Lett.,238(1): 189-197.

39. Bono, J.L., Keen, J.E. and Miller, L.C. (2004) Evaluation of a real-time PCR kit for detecting Escherichia coli O157 in bovine fecal samples. Appl. Environ. Microbiol., 70: $1855-1857$

\section{$* * * * * * * *$}

